\title{
SYSTEMS OF LIFE
}

\section{VOLUME I}

Anne Roberts and Peter Gardiner 
(C) Macmillan Magazines Ltd 1993

All rights reserved. No reproduction, copy or transmission of this publication may be made without written permission.

No paragraph of this publication may be reproduced, copied or transmitted save with written permission or in accordance with the provisions of the Copyright, Designs and Patent Act 1988 or under the terms of any licence permitting limited copying issued by the Copyright Licensing Agency, 33-4 Alfred Place, London WCIE 7DP.

Any person who does any unauthorised act in relation to this publication may be liable to criminal prosecution and civil claims for damages.

First edition 1992

Reprinted 1993

Published by

Macmillan Magazines Itd

4 Little Essex Street

London WC2R 3LF

Companies and representatives throughout the world

ISBN 978-0-333-57860-5

ISBN 978-1-349-12988-1 (eBook)

DOI 10.1007/978-1-349-12988-1 
CONTENTS

INTRODUCTION 2

CARDIOVASCULAR SYSTEM

Part 1

Part 2

3

7

RESPIRATORY SYSTEM

Part 1

Part 2

11

15

DIGESTIVE SYSTEM

Part 1

19

Part 2

23

Part 3

27

Part 4

31

URINARY SYSTEM

35

REPRODUCTIVE SYSTEM

Part 1

39

Part 2

43

Part 3

47 